\title{
Pensamento social, ciência e imagens do Brasil: tradições revisitadas pelos educadores brasileiros
}

\author{
Marcos Cezar de Freitas \\ Universidade São Francisco \\ Centro de D ocumentação e A poio à Pesquisa em História de Educação
}

\section{D ualismo e privatismo: arqueologia dasquestões intelectuaisdos educadores do século XX}

Em 1901, Euclides da Cunha preparou o material necessário para a conclusão do livro Os sertões, que seria publicado no ano seguinte. Naquela ocasião, pareceu-lhe necessário fazer uma advertência ao leitor de que as personagens que seriam ali retratadas, como o "jagunço destemeroso, o tabaréu ingênuo e o caipira simplório" deveriam ser consideradas figuras em extinção, representantes que eram de uma tradição que se esvanecia diante de uma "verdade" considerada implacável pelo autor, a de que a civilização haveria de superar a barbárie (Cunha, 1996, p. 8).

A Guerra de Canudos, retratada num texto de enorme repercussão, rapidamente tornou-se um marco simbólico. Mais do que um livro-reportagem, o épico Os sertões passou a ser citado como uma fundação argumentativa exemplar da identidade nacional. Sobre este "fundamento", inúmeros textos históricos, sociológicos, antropológicos e literários compuseram as narrativas que - em boa parte do século vinte - quiseram revelar a distância entre o país que se conhecia e o país que ainda deveria ser conhecido, ambos o mesmo Brasil.

Impressiona o quanto repercutiu a literatura produzida por Euclides da Cunha. Mesmo que assentado em cientificismos evolucionistas e em incontáveis estereótipos de raça, o resumo do país apresentado na abertura do século tornava o sertão uma metáfora para toda a nação (Lima, 1999). Acima de tudo, o sertão tornou-se uma metáfora da ausência. Euclides reclamava da falta de unidade racial e da inexistência de unidade temporal num país dividido em vários tempos históricos. Faltava o Estado, faltavam a educação e a saúde.

Tais estruturas ausentes, contudo, estavam timidamente presentes na pequena vida urbana que o país possuía. As cidades, porém, estavam de costas para o sertão. Por isso, Euclides da Cunha escrevia como quem estivesse "em missão", conclamando os analistas do Brasil a descobrir o país real (Sevcenko, 1985). Quando afirmou que a sociedade brasileira estava condenada à civilização e que, por isso, deveria progredir para que não desaparecesse, lavrou um testamento interpretativo que se fez presente nas análises de muitos "herdeiros" da argumentação euclidiana (Cunha, 1996, p. 42). 
Gilberto Freyre observou que a atenção voltada para os escritos de Euclides da Cunha, que alcançavam leitores europeus e americanos, derivava da capacidade exibida pelo autor de Um paraíso perdido de misturar literatura com ciência. Esse prodígio o tornava uma expressão de nosso exotismo e do peculiar tropicalismo que nos caracterizava desde o século XVI, como a obra do próprio Freyre quis comprovar (Freyre, 1976, p. 15).

Entre a ficção e o cientificismo, as representações do Brasil bárbaro oposto ao Brasil civilizado consolidaram-se como chave de leitura histórica e, enquanto se multiplicavam, provocavam várias perplexidades. Entre estas, a idéia de que os "brasis regionais" eram incompatíveis com o Brasil nação era, por assim dizer, a perplexidade maior. Um fragmento de carta de Monteiro Lobato revela um sentimento que se generalizava nas primeiras décadas do século:

O Brasil ainda é uma horta, Rangel, e em horta, o que se quer são cebolas e cebolorios, coentros e couves tronchudas, tomates e nabo branco chato francês. Não somos ainda uma nação, uma nacionalidade. As enciclopédias francesas começam o artigo Brasil assim: une vaste contrée... Não somos país, somos região. O que há a fazer aqui é ganhar dinheiro e cada um que viva como lhe apraz aos instintos. (Lobato, in De Luca, 1999)

Nesse acervo de imagens, a referência à realidade nacional tornou-se uma constante. A formação de escolas interpretativas, de campos intelectuais (Miceli, 1979) e de sínteses históricas, muitas vezes justificou o empenho racionalizador presente nos escritos que buscavam desvendar a realidade. O Brasil real estaria oculto num "Estado que não era uma nacionalidade, num país que não era uma sociedade, numa gente que não era um povo (Torres, 1933, p. 297).

A impressão de dualidade, ou seja, a alusão a uma realidade cindida entre o que se conhece e o que se esconde, somada à dicotomia entre cidade e campo, tornou-se constante em muitos escritos que, a partir de 1870, quiseram explicar as causas dessa "esquizofrenia" social (Arantes, 1992; Carvalho, 1998; Freitas, 1999).

Para proceder a um exame mais detalhado do processo de formação da comunidade de intelectuais da educação no Brasil, entre o início dos anos vinte e o final dos anos sessentas, é necessário levar em consideração o impacto desse sentimento de dualidade na elaboração dos principais escritos dos intelectuais educadores que ocuparam a cena nesse período. Claramente a referência diz respeito a Anísio Teixeira, Fernando de Azevedo, Vicente Licínio Cardoso, Lourenço Filho, Paschoal Lemme, e a vários outros que, no âmbito universitário, tornaram-se, anos mais tarde, interlocutores desse grupo, tais como Florestan Fernandes, Antonio Candido, Luiz Pereira etc. Nas formas, através das quais, tais figuras públicas receberam imagens do Brasil dual e nas formas, pelas quais, tais imagens foram reelaboradas nos escritos de cada qual, pode-se observar uma rica experiência intelectual, das mais expressivas do século.

A trajetória intelectual que envolve os educadores brasileiros no século vinte possui dois momentos vigorosos. O primeiro momento foi o dos anos vinte e trinta, nos quais se interpelava o Estado a construir a obra educativa necessária à equiparação dos muitos brasis. Os ecos dos sertões na grita de Euclides da Cunha reverberavam com força. Ir ao interior, desbravar o sertão e conhecer o país significava - na tradição euclidiana voltar ao passado, retroceder no tempo, conhecer aquele homem brasileiro visto então como que em outra etapa histórica, quase que em outra esfera mesológica.

É necessário lembrar que entre 1916 e 1920 um forte movimento sanitarista ocupou o debate intelectual brasileiro. O saneamento do interior, dos sertões, ajudava a dar visibilidade ao intelectual médico que atuava como uma espécie de antropólogo. Os debates sobre a identidade do país naqueles anos foram fortemente influenciados pelas discussões em torno às questões raciais da cultura brasileira. As iniciativas de personalidades como Carlos Chagas e Miguel Pereira, em conjunto com as ações do Instituto Oswaldo Cruz, propunham um projeto de civilização para o país. Miguel Pereira chegava a dizer que o Brasil era um imenso hospital (Lima \& Hochman, 1996, p. 23). Todas essas questões serão retomadas no processo de constituição da comunidade de educadores profissionais, no Brasil.

$\mathrm{Na}$ fala dos educadores, cada vez mais, o reconhecimento de que a República não havia cumprido sua promessa educacional significava dizer que boa parte da nação não fora ainda tirada do passado e projetada para 
o futuro. Perdidos em tempos distintos, os brasileiros precisariam ser conhecidos, a realidade precisaria ser enfrentada e, acima de tudo, seria necessário impedir que as configurações regionais continuassem a inviabilizar a nova configuração nacional que se buscava. Um ícone desse momento foi o manifesto $A$ reconstrução educacional no Brasil - ao povo e ao governo, de 1932, quase que uma síntese do pensamento social brasileiro nas primeiras décadas de República.

O segundo momento de vigor intelectual ocorrerá na segunda metade da década de cinqüenta, quando o Centro Brasileiro de Pesquisas Educacionais promoveu um novo mergulho no espelho de Euclides. A pesquisa educacional, que se somava à pesquisa sociológica e antropológica, passou a fazer um movimento inverso em relação ao momento anterior. Nesse segundo contexto, a tentativa de conhecer a realidade nacional tornava necessário mergulhar na realidade microscópica, na singularidade de cada lugar, quem sabe até, de cada escola. Permanecia, segundo muitos, ainda um país dual a ser unificado. Mas o sentido de intervenção intelectual era outro. De forma emblemática, um novo Manifesto despontou em 1959: o Manifesto dos educadores mais uma vez convocados.

O ponto de partida para compreender a elaboração de imagens do Brasil por parte dos intelectuais da educação é, seguramente, a análise da sobrevivência dos paradigmas euclidianos junto a tais educadores, bem como a análise das reelaborações que essas imagens sofreram à medida que muitos educadores se tornaram ensaístas com luz própria.

Também é necessário levar em consideração que boa parte do pensamento educacional brasileiro do século vinte esteve muito envolvido com a necessidade política de defender a escola pública. Isso conduziu vários educadores, muito especialmente Anísio Teixeira, a elaborar sínteses históricas com o objetivo de refutar, recorrendo aos exemplos do passado, o predomínio da esfera privada sobre a esfera pública. Essa personalidade privada que a sociedade brasileira possuía era relacionada à colonização portuguesa que mantivera o país à mercê da cultura da Contra-Reforma, entendida como uma espécie de multiplicadora das tradições medievais. A leitura de autores como Nestor Duarte oferecia ele- mentos com os quais se lamentava a ausência de uma ordem política efetivamente pública, com o que percebia-se que há séculos o Brasil era "privado por dentro", (Duarte, 1966).

Por ocasião dos debates sobre a da Lei de Diretrizes e Bases da Educação Nacional, as polêmicas em torno a Anísio Teixeira deixavam claro porque a questão do privatismo tornava-se uma questão também intelectual e de grande exigência investigativa e argumentativa (Buffa, 1979; Freitas, 1998; Werebe, 1970). Um argumento expresso na Revista de Cultura Vozes, constantemente repetido nos anos sessentas, pode ser usado como exemplo eloqüente:

Criou-se uma idéia falsa a respeito do termo público. É como se dissessem: dinheiro oficial, só para a escola oficial. Entretanto, não há dinheiro do Estado [...]. O dinheiro é do povo, que entrega ao Estado, para que reverta a favor do povo. Assim escola pública é a escola que o Estado tem que abrir ao povo. No dia que o Estado possua o seu próprio dinheiro, está certo que faça com ele o que entender. [...] Se a escola particular for aberta ao povo, é tão pública quanto a escola oficial. E é isto que queremos: multiplicar as escolas do povo. Para que se julgue da exata aplicação do vocábulo público vejam-se estas expressões: lugar aberto ao público, (será lugar oficial?) e mulher pública (será mulher oficial?). (Revista de Cultura Vozes, 1961, p. 198)

Tal argumentação correspondia a uma representação da singularidade brasileira. Tentava-se argüir que, conforme a realidade nacional, uma instituição poderia ter uma "natureza" pública, ainda que fosse privada. Sabemos que esse argumento nunca mais cessou de aparecer.

Em relação ao tema realidade nacional, a inteligência educacional brasileira primeiro dialogou com e depois distanciou-se de uma tradição argumentativa originada no século XIX e que se prolongou até os anos cinqüentas do século XX. Essa tradição foi marcada por concepções antiliberais que ostentavam uma idéia de realismo com a qual se tentava comprovar a inaptidão do Brasil à cultura política européia e norte-americana. São representantes dessa tradição Paulino Soares José de Souza, que era o Visconde do Uruguai, depois Silvio Romero, Alberto Torres, Oliveira Vianna e, mais tarde, 
Alberto Guerreiro Ramos (Silva, 1965, p. 3; Carvalho, 1998, p. 208). É importante traçar, ainda que brevemente, o perfil dessa tradição para entender como os educadores do Brasil procederam intelectualmente para se distanciar de paradigmas tão influentes. Nos anos cinqüentas, os educadores provocarão uma sensível inflexão no trato da idéia de realidade nacional. Farão esse deslocamento mediante a revisão da idéia de regional com a qual trabalhavam. $\mathrm{O}$ dualismo, nessa trajetória intelectual que configurou novos campos de pesquisa, passou a ser um signo constantemente revisitado. O privatismo, por sua vez, tornou-se o componente econômico/político continuamente exorcizado. Para tornar essa análise mais clara é necessário recuperar alguns argumentos com os quais os temas da transplantação de idéias e do conhecimento da realidade foram tratados anteriormente. Dessa forma, será possível perceber as imagens de Brasil que os intelectuais da educação receberam e, para além disso, as imagens que teceram por "conta própria".

\section{0 nacional, o regional e a idéia deculturatransplantada}

A percepção de que o país, ao menos no imaginário intelectual, era representado como uma região do mundo e não como uma nacionalidade fortemente afirmada e reconhecida, tornou-se uma questão tanto teórica quanto, política a partir de meados do século XIX, acentuando-se muito em 1870, quando a crítica ao regime monárquico subiu de tom.

Os desequilíbrios presentes na sociedade brasileira passaram a ser citados com mais veemência. A escravidão, como só podia ser, consolidou-se como "a grande questão a ser enfrentada, resolvida e ultrapassada”. De José Bonifácio a Joaquim Nabuco, o tema da escravidão foi tratado como sendo um impeditivo à existência de um Brasil civilizado. O trabalho escravo era a base estrutural de um país organizado conforme suas desigualdades e seus privilégios. No Manifesto do Partido Republicano de 1870 a percepção dessa situação foi assim retratada:

O privilégio, em todas as suas relações com a socieda-

de - tal é, em síntese, a fórmula social e política do nosso

País - privilégio de religião, privilégio de raça, privilégio de sabedoria, privilégio de posição, isto é, todas as distinções arbitrárias e odiosas que criam no seio da sociedade civil e política a monstruosa superioridade de um sobre todos ou a de alguns sobre muitos. A esse desequilíbrio de forças, a essa pressão atrofiadora, deve o nosso País a sua decadência moral, a sua desorganização administrativa e as perturbações econômicas, que ameaçam devorar o futuro depois de haverem arruinado o presente. A sociedade brasileira, após meio século de existência como coletividade nacional independente, encontra-se hoje, apesar disso, em face do problema da sua organização política, como se agora surgisse do caos nacional.

Como se percebe, mesmo sendo bastante jovem, o Estado nacional era considerado "atrofiado" e, por isso, preso em seus problemas. Para além da supressão do trabalho escravo e da adoção do regime republicano, questões que seriam concluídas na década seguinte, cada vez mais o combate aos desequilíbrios nacionais tornou-se componente de um debate polifônico, para o qual revelar a identidade nacional significava primeiramente assumir uma postura diante do mundo ocidental e, em seguida, escolher quais dentre as "idéias importadas" eram compatíveis com um país desde cedo considerado peculiar. Ao mesmo tempo, todas essas questões tornavam-se "objeto de ciência".

Solucionar os problemas sociais resultantes da abolição da escravidão e cumprir as exigências necessárias para tornar a República brasileira efetivamente uma res publica, favorecia o surgimento de plataformas políticas (Janotti, 1997) e de novos nacionalismos (Oliveira, 1990). No mesmo contexto, médicos e antropólogos pronunciavam teorias que tentavam, por intermédio da análise de nossos componentes raciais, sustentar hipóteses que anunciavam a "necessidade de branquear a sociedade" (De Luca, 1999, Maio \& Santos, 1996; Skidmore, 1976). Tudo isso era feito e discutido em nome da construção da nacionalidade

A busca de soluções próprias somada ao elogio do autoconhecimento tornou-se uma tradição brasileira. José Murilo de Carvalho lembra que esse componente tradicional ganhou forma articulada nos escritos do Visconde do Uruguai (Carvalho, 1998, p. 208-209). O jurista, embora fosse um estudioso da organização de outros países, especialmente da Inglaterra, da França e dos Estados Unidos, considerava arriscada a implantação das 
instituições de um lugar em outro. Afirmava isso porque acreditava que as leis e instituições decorriam das tradições de cada local. Dissociar a lei dos costumes significava tornar inadequada a relação entre a regra e a prática social, posto que esta deveria ser a base para aquela. Além do mais, o Visconde do Uruguai inaugurou uma reflexão que considerava possível desenvolver uma "técnica de governo" segundo a qual o elemento político da sociedade pudesse ser dissociado do elemento administrativo. Sua fala tentou ser suficientemente didática para que pudesse ser entendida como pré-requisito ao debate sobre a organização do país:

Quando uma nação tem instituições administrativas conformes com os bons princípios, úteis, protetoras, arraigadas nos hábitos da população, os novos governos, dada uma mudança política, servem-se delas; apenas modificam uma ou outra base, um ou outro princípio, mas não as destróem, nem podem destruir. Servem contudo de garantias. Quando o país não tem essas instituições, ou as tem mal concebidas, mal assentadas, mal desenvolvidas, cada mudança política traz completa mudança administrativa, e o arbítrio revolucionário não encontra empecilho algum. [...] A administração é a força viva que torna a lei ativa e sensível. É o instrumento organizado que dá à lei o poder exterior, e que imprime o movimento nos negócios públicos. (Souza 1862, p. 27-31)

A busca de instituições adequadas ao perfil complexo que o país exibia manifestou-se em muitos outros estudos e, a partir de Silvio Romero, tal questão passou a ser associada a uma realidade mestiça, porque composta de um povo mestiço (Candido, 1988, p. 43). O autor da História da literatura brasileira propunha uma metodologia de análise para o conhecimento da realidade nacional, considerada por ele escondida sob o manto da diversidade. Metodologicamente considerava necessário dividir o país em zonas e, em cada uma delas, verificar as várias "classes de população" com os seus múltiplos estilos de vida (Romero, 1910 in Menezes, 1998, p. 215-221).

Em relação ao debate antropológico de então, Silvio Romero avançava ao denunciar a "vergonha" que vários estratos sociais sentiam em relação à personalidade miscigenada do país. Porém, ao tecer considerações sobre o "branqueamento da sociedade" e sobre as relações entre o homem e seu meio, abriu caminho para uma sociologia que, em nome da ciência, não cessava de reeditar concepções discriminatórias em relação ao elemento não-branco da sociedade brasileira.

Romero fazia um movimento pendular com qual ora reclamava da ausência de estudos sobre as raças na composição do folclore brasileiro, ora trazia para o nosso meio idéias naturalistas e evolucionistas de autores europeus. Os traços multirraciais da sociedade brasileira, no seu entender, inviabilizavam a "assimilação acrítica" de teorias estrangeiras. A abordagem do ensaísta inaugurou o processo de articulação entre a integração racial e a mestiçagem com a construção de mitos da identidade brasileira. Euclides da Cunha seguiu-o de perto.

Silvio Romero não vestiu as roupagens de nacionalista ou romântico. Mesmo quando interpelou a sociedade a "mergulhar para dentro" para que se pudesse perceber a questão da mestiçagem como mérito de ciência, não se tornou um nacionalista, no sentido que essa palavra adquiriu na Primeira República. Se a miscigenação era o dado indicativo da particularidade do país, o reconhecimento do dado particular, no seu entender, deveria ser um movimento em direção à universalidade (Candido, 1988, p. 48).

Quando Silvio Romero assinalou o "caráter inautêntico da cultura brasileira", quis instrumentalizar a crítica - no sentido de prevenir a adoção de categorias estrangeiras - e preparar a elucidação de problemas somente compreensíveis ao analista mergulhado no realismo próprio das culturas multiétnicas:

Todo brasileiro é um mestiço, quando não no sangue, nas idéias. Os operários deste fato inicial hão sido: o português, o negro, o índio, o meio físico e a imitação estrangeira.

(Romero, 1881, p. 232-233)

Essa abordagem serviu de base para a sua análise "sociológica", com a qual observou a complexidade étnica do país. Silvio Romero aproveitou essa particularidade étnica para tratar do "caráter nacional brasileiro" (Leite, 1992, p. 181-185). Nas palavras do próprio autor:

Quando falo no mestiço não quero me referir somente ao mestiço fisiológico - o mulato; refiro-me a todos os filhos da colônia, todos os crioulos, que o eram num sentido lato; 
porquanto ainda, que nascessem de raças puras, o eram no sentido moral. Eu me explico. Tomem os leitores uma fazenda, um engenho do primeiro século, e apreciem as circunstâncias desta espécie de mestiçagem moral... Os filhos do senhor de engenho eram de certo limpos de tez; mas gostando muito de ir às senzalas a conversar e brincar com os moleques, as pretas e as caboclas velhas, saíam no fim de contas uns portuguesitos, é verdade, mas uns tais, que distavam dos pais, como a água do vinho, pela intuição e pela face moral... Por outro lado, os filhos dos escravos, os filhos dos pretos e dos índios, perdiam a língua do senhor; eram cristianizados e aprendiam umas tantas coisas que só os brancos sabiam... Eis aí o que eu chamo de mestiçagem moral. (Romero, 1888, v. I, p. 171-172)

A questão racial perfilada dessa forma antecipa algumas conclusões que seriam expressas por Gilberto Freyre nos anos trintas.

Euclides da Cunha, leitor de Ratzel, valeu-se da mesma percepção sobre a complexidade etnológica brasileira para enveredar-se pelas trilhas de determinismos que expressavam a história da evolução dos povos como resultado de sua evolução étnica. Essa dificuldade em separar o dado biológico do social abriu caminho para a assimilação de conceitos formulados no âmbito da antropogeometria e da antropometria (Ramos, 1957, p. 131-132). Não se deve esquecer que a sombra de Nina Rodrigues pairava sobre as análises socioantropológicas. As considerações sobre o "necessário" branqueamento da sociedade brasileira, a valorização das medidas antropométricas e a leitura de autores como Lombroso faziam de Nina uma referência a mais no estoque de idéias e estereótipos com os quais a cultura brasileira era analisada e problematizada.

Conhecer o país passou então a significar adesão a postulados científicos forjados fora do Brasil mas que, paradoxalmente, alimentavam sentimentos de rejeição à transplantação de idéias. O país mestiço passou a ser entendido como a porção mais autêntica, ainda que problemática. Embora Euclides da Cunha vaticinasse: "progredir ou desaparecer", apontando a necessidade de urbanizar o homem rural e subtraí-lo à barbárie, ainda assim, o homem embrutecido do sertão passou a ser representado como portador de uma essência que se confundia com a própria essência da nacionalidade.
Um ingrediente notoriamente nacionalista foi acrescentado a essa tradição por Alberto Torres, influente jurista cujas palavras reverberavam ainda no Manifesto dos Pioneiros de 1932. Torres propalava a necessidade de investigar a realidade nacional para que a distância entre o regional e o nacional fosse diminuída.

Na virada do século, debatia-se no Parlamento brasileiro se o país possuía ou não vocação para a industrialização. Opunham-se tendências que antagonizavam as idéias de "indústria natural" e de "indústria artificial". A primeira estava relacionada à personalidade agrícola que supostamente o país teria. No ruralismo estaria concentrado o conjunto de possibilidades para que o crescimento econômico pudesse autonomizar a nação em relação ao imperialismo, palavra que passa a fazer parte do vocabulário político na primeira década do século. Em oposição, a indústria artificial seria a indústria mecânica propriamente dita, pensada então no feitio inglês (Luz, 1978).

Para Alberto Torres, conhecer a realidade e, ao mesmo tempo, apartar-se da tentação à transplantação de idéias para explicar a realidade nacional significa reconhecer que:

O Brasil tem de ser uma república social por força de seu destino, e da fatalidade de seu surto na era da questão social; e tem de ser, intuitivamente, uma república agrícola. É preciso que seja, porém, uma república social, prudente e conservadora, para que o povo não sinta um dia a necessidade de arrancar à força o que os governos podem lhes dar dentro da ordem. (Torres, 1938a, p. 168-169)

$\mathrm{O}$ argumento mais influente derivado da obra de Alberto Torres, para além da apologia do país estruturalmente agrícola, foi o da necessidade de modernização das instituições nacionais. Essa necessidade, no seu entender, decorria dos desequilíbrios que a sociedade herdou da antiga ordem monárquica/escravocrata. Somava-se a tais considerações uma agressiva rejeição à civilização urbanoindustrial, considerada desagregadora e competitiva em excesso:

O desequilíbrio das sociedades modernas resulta, principalmente, da deslocação constante das populações das zonas rurais para as indústrias, do esforço produtivo para as manufaturas e para o comércio. O Brasil tem por destino evi- 
dente ser um país agrícola: toda a ação que tenda a desviá-lo desse destino é um crime contra sua natureza e contra os interesses humanos [...]. No estado de desequilíbrio entre a distribuição das populações e o aproveitamento das terras, que caracteriza uma das faces mais graves do problema mundial, o destino do Brasil não pode ser o de oferecer novas regiões a explorar e novas riquezas às ambições imediatas dos povos superpovoados ou excessivamente ricos, mas o de ir realizando, à medida que o estudo dos problemas da sua natureza permitir, com a instalação quase patriarcal a princípio dos colonos, e com o estabelecimento agrícola de caráter mais industrial, depois, a solução do problema fundamental da sociedade contemporânea que consiste em fazer regressar o homem ao trabalho da produção - as indústrias da terra. (Torres, 1938b, p. 214)

Estamos diante de uma tradição interpretativa que deu início a uma operação analítica sui generis. Tais autores tentavam dar estatuto epistemológico à rejeição ao ocidente e à cultura letrada dele derivada. Fizeram tal movimento de idéias muitas vezes lançando mão do acervo interpretativo herdado da própria cultura européia, especialmente do Positivismo francês. Mas, a rejeição ao ocidente externo muitas vezes projetou um ocidente interno, quando cidade e campo foram opostos com a mesma distância entre civilização e barbárie presente nas representações da relação ocidente/oriente ou Europa/América.

Não à toa, Alberto Torres considerava necessário formar a nação "de cima para baixo", por obra e ação de um Estado forte. Os projetos mantinham sempre um tom civilizador, para o que a força, ainda que simbólica, era considerada uma ferramenta necessária.

Salientava-se que conhecer a realidade correspondia a investigar "a nossa terra e a nossa gente" (Torres, 1915, p. 19). Nesse sentido, o sertanejo precisaria "ser salvo", ao mesmo tempo, de si e do homem da cidade. Cumpria educar o homem do campo e, ainda assim, mantê-lo como homem do campo:

A obra educadora do nosso tempo terá de fazer nestas

inteligências um trabalho de sapa, que não é ousado equiparar ao da civilização dos selvagens. (Torres, 1938a, p. 144)

Já que a tarefa de organizar a nação cabia, antes de mais nada, ao Estado, a plataforma de realizações era até simplificada:
[...] demos terras a todos os homens válidos; instrução primária a todos os que podem ver e ouvir; instrução secundária e superior a todos os que são capazes, não dando a nenhum que não o seja. (Torres, 1938a, p. 173)

Esse "receituário" fez escola.

Oliveira Vianna foi um continuador da obra de Alberto Torres, alcançando, contudo, maior prestígio. Alguns de seus escritos, tais como Evolução do povo brasileiro ou Populações meridionais no Brasil, a despeito da controvérsia que provocaram, desde cedo foram reconhecidos como "sínteses do Brasil".

Oliveira Vianna retratou o Brasil como país essencialmente rural, cujas origens patriarcais teriam sido as responsáveis pela divisão do país em clãs, os quais inviabilizavam o surgimento de uma cultura pública que não fosse implantada por um Estado forte e centralizador. Era um pensador autoritário que considerava anticientífico aplicar no Brasil idéias urdidas em outros países. Com essa opinião, rejeitava simultaneamente o liberalismo e o socialismo.

Era fundamentalmente um modernizador. Pleiteava uma nova organização institucional ao país com vistas a produzir uma nova ordem sem os desequilíbrios visíveis até então. Defendia a utilização de uma "técnica autoritária”, com a qual o país fosse dividido em corporações profissionais. $\mathrm{O}$ voto exercido dentro de cada corporação criaria, no seu entender, uma representação mais adequada ao país, sem os desvios que as constituições liberais provocavam desde 1824, muito especialmente, desde a constituição de 1891.

Vianna continuou a tradição que recebeu e revitalizou a percepção de que um país agrícola vivia à margem do país urbano, no qual o conflito entre o Direito-lei e o Direito-costume, produzia um conhecimento artificial e inadequado à realidade. Nesse sentido, repetiu a fala de seus antecessores e assinalou a distância entre o país legal e o país real.

Para o jurista, conhecer a realidade brasileira exigia uma análise histórica através da qual se percebesse a diferença introduzida pela colonização portuguesa em relação aos demais países de colonização européia. A colonização anglo-saxônia, segundo ele, havia plantado instituições de autogoverno e forjado uma estrutura de democracia direta, diferentemente do português, que ha- 
via semeado uma mentalidade privatista. A democracia era incompatível com a "personalidade do país", formada em clãs. Diante desse passado, considerava que apenas uma saída autoritária conduziria a um futuro melhor.

No seu entender, noções como as de coisa pública estavam ausentes desde os primeiros momentos de ocupação e não se constituíram na formação do Estado brasileiro autônomo:

Caracterizada pela rarefação e adelgaçamento da massa povoadora, pela dispersão dos moradores por uma base territorial imensa e inculta, apenas percorrida calcante pede pelo povo-massa e carecente quase em absoluto de comunicações espirituais, tinha que acabar, como acabou, por enformar o homem, criando-lhe um tipo humano adequado a essa disposição dispersiva, individualística e atomística. E criou o homo colonialis, amante da solidão e do deserto, rústico e antiurbano, fragueiro e dendrófilo, que evita a cidade e tem o gosto do campo e da floresta. Homem de que a expressão mais acabada e representativa é o paulista do bandeirismo - telúrico, eruptivo, abrupto, tal como as rochas de gnaisse e manganês de seu habitat formador. (Vianna, 1974, v. I, p. 118)

Homem e meio ambiente continuam no espelho de Euclides, ou seja, permanecem profundamente imbricados. As imagens produzidas pelo jurista expõem um país acima de tudo incapacitado a trazer para si as experiências de outros lugares. Oliveira Vianna supunha estar fazendo uma apreciação comprovável empiricamente:

O erro dos nossos reformadores políticos tem sido querer realizar aqui - no meio desses nossos rudimentarismos de estrutura e de cultura política - uma democracia de tipo inglês. Porque sejam quais forem as combinações e arranjos constitucionais que engenharem, seja qual for a pregação dos novos Rui do futuro, estaremos condenados a jamais ser ingleses. (Vianna, 1974, v. II, p. 131)

Segundo suas conclusões, diante da impossibilidade de transformar o país numa nova Inglaterra, o caminho a seguir seria o da recusa radical à chamada transplantação de idéias. "Cientificamente" considerava que não existiam condições para a repetição da experiência histórica realizada alhures:
[...] o sufrágio universal e o sufrágio igual é anticientífico, quando aplicado sistematicamente a nosso povo. Pela pluralidade de sua estrutura cultural e pela diversidade de sua estrutura ecológica, o nosso povo está exigindo também uma pluralidade de sistemas eleitorais ou, mais exatamente - uma pluralidade de eleitorados. (Vianna, 1974, v. II, p. 156)

Seus cuidados em relação às garantias do pleno exercício das liberdades civis passavam pelo resgate da população em relação aos séculos de feudalismo e de convivência com clãs. Esse resgate, necessariamente, deveria ser feito no bojo de um processo de reeducação de nossas elites:

O nosso grande problema, como já disse alhures, não é acabar com as oligarquias; é transformá-las, fazendo-as passar de sua atual condição de oligarquias broncas para uma nova condição - de oligarquias esclarecidas. Estas oligarquias esclarecidas seriam, então, realmente, a expressão da única forma de democracia possível no Brasil; porque realizada na sua forma genuína, isto é, no sentido ateniense - governo dos melhores. (Vianna, 1974, v. II, p. 150)

Todas as imagens de Brasil produzidas no seio da obra de Oliveira Vianna expressavam o que o autor chamava de realismo. Essa hermenêutica interpretativa resultava de uma fala que se proclamava científica. Resultava também da apropriação de uma determinada leitura histórica, segundo a qual elementos atávicos impediam a superação do atraso no qual o Brasil estava mergulhado. Realismo, história e ciência vinham sendo evocados desde o Visconde do Uruguai, desde Silvio Romero, desde Alberto Torres e, já em Oliveira Vianna, consolidam-se como componentes de uma tradição intelectual com continuidade e afinidades conceituais.

No após Estado Novo, o intento de conhecer a realidade e interpretar as dificuldades presentes na história de um povo cindido em dualismos tornou-se um desafio intelectual também para Alberto Guerreiro Ramos, talvez o último representante dessa tradição.

Guerreiro Ramos, contudo, não pode ser considerado simplesmente um continuador em relação àqueles autores. Em sua obra, apreciou os escritos de cada um deles e, em alguns casos, posicionou-se criticamente em relação ao legado deixado pela "tradição realista". Mas 
não se pode negar, entretanto, que o polêmico sociólogo levou adiante, com muita ênfase, a crítica à transplantação de idéias e a leitura da sociedade brasileira tomando por base o dualismo do país legal versus país real (Ramos, 1957 e 1965).

Se esse é o ponto de continuidade em relação aos outros autores, o ponto de inflexão é simbolicamente importante. Alberto Guerreiro Ramos já não faz parte da plêiade de intelectuais que lamentam o atraso da nação. Em vez de atrasada, Guerreiro considerava a realidade brasileira subdesenvolvida, e essa era uma diferença substantiva. A mudança do marco teórico era uma decorrência da assimilação dos parâmetros interpretativos oferecidos pela Comissão Econômica para a América Latina - CEPAL -, que desde 1948 tornou-se bastante influente, graças ao prestígio alcançado pela novas interpretações econômicas oferecidas por Raul Prebisch e Celso Furtado (Freitas, 1998).

Guerreiro Ramos tornou-se, como tantos nos anos cinqüentas, intérprete do processo de transição pelo qual passavam as nações do Terceiro Mundo, expressão geopolítica cuja utilização disseminava-se naquele momento.

Parte expressiva do pensamento social brasileiro, após a Segunda Guerra, revigorou a hipótese de que a história possui fases que se sucedem. Na sucessão de uma após outra, cumpria à inteligência nacional adequar e planejar as ações necessárias para cumprir os "requisitos históricos" da fase que se vivia, sem antecipações improdutivas e sem retardamentos comprometedores.

Guerreiro Ramos propunha a adoção da sociologia como um "saber de salvação", o que significava propor um novo procedimento científico para conhecer a realidade (Ramos, 1965, p. 15). Esse procedimento baseava-se no reconhecimento de que, no Brasil, tempos históricos distintos conviviam, de modo que várias etapas da história da humanidade podiam ser identificadas na mesma conjuntura nacional (Oliveira, 1995b, p. 48).

Reedita-se, dessa forma, a versão dual dos dois países convivendo num só. Para compreender a complexidade de uma nacionalidade sujeita a tal peculiaridade, seria necessário, no seu entender, proceder a uma redução sociológica (Ramos, 1965, p. 100).
A redução significava uma exacerbada reação à transplantação de idéias. Considerava que o acervo teórico e analítico preexistente deveria ser considerado parcialmente aproveitável no Terceiro Mundo, uma vez que fora acumulado sobre outra experiência histórica. Se o país estava procedendo, naquela hora, a uma substituição de importações, deveria, da mesma forma, substituir conceitos estrangeiros por conceitos nacionais, ou seja, reduzir a sociologia estrangeira, chamada por ele de "enlatada", à realidade nacional:

Em seu sentido mais genérico, redução consiste na eliminação de tudo aquilo que, pelo seu caráter acessório e secundário, perturba o esforço de compreensão e a obtenção do essencial de um dado. E, portanto, a redução, seja praticada no domínio teórico, seja no domínio das operações empíricas, é sempre a mesma atividade. A redução de uma idéia ou de um minério, por exemplo, consiste em desembaraçá-los de suas componentes secundárias para que se mostrem no que são essencialmente. No domínio restrito da sociologia, a redução é uma atitude metódica que tem por fim descobrir os pressupostos referenciais, de natureza histórica, dos objetos e fatos da realidade social. A redução sociológica, porém, é ditada não somente pelo imperativo de conhecer, mas também pela necessidade social de uma comunidade que, na realização de seu projeto de existência histórica, tem de servir-se da experiência de outras comunidades. (Ramos, 1965, p. 81-82)

Essa redução, que consistia na eliminação dos componentes explicativos não relacionados à comunidade local, proporcionou argumentos com os quais o autor defendeu a existência de uma ciência própria para o mundo subdesenvolvido e outra própria para o mundo desenvolvido. Mesmo que o enfoque recaísse sobre o projeto de reconstrução da nacionalidade, predominava o intento de produzir e resguardar o conhecimento local:

É um procedimento crítico-assimilativo da experiência estrangeira. A redução sociológica não implica isolacionismo, nem exaltação romântica do local, regional ou nacional. É, ao contrário, dirigida por uma aspiração ao universal, mediatizado, porém, pelo local, regional ou nacional. [...] Uma sociedade onde se desenvolve a capacidade de auto-articular-se, torna-se conscientemente seletiva [...]. Diz-se aqui conscientemente seletiva, pois em todo grupo social há uma seletividade inconsciente que se incumbe de distorcer ou reinterpretar os produ- 
tos culturais importados, contrariando, muitas vezes, a expectativa dos que praticam ou aconselham as transplantações literais. (Ramos, 1965, p. 83-84)

A proposta de uma sociologia adaptada às condições locais da economia subdesenvolvida suscitou muitas polêmicas. A crítica mais contundente partiu de Florestan Fernandes.

O sociólogo paulista considerou que as exigências de rigor na análise sociológica independiam das dificuldades presentes em cada estrutura social. Essas dificuldades poderiam até inviabilizar o trabalho do analista, mas, no seu modo de entender, não autorizavam a "adaptação" de categorias a essa ou aquela realidade (Fernandes, 1980, p. 70).

Metodologicamente, naquele momento, Florestan Fernandes não se utilizava da crítica à transplantação de idéias. Ao contrário, valia-se muito do acervo histórico/sociológico preexistente para reclamar rigor no trabalho sociológico. O ponto de afastamento entre Guerreiro e Florestan estava centrado na recusa do segundo de fazer uma sociologia "engajada" (Fernandes, 1980, p. 67-68). Por sua vez, Guerreiro reivindicava a autoria de uma "sociologia em ato" ou de uma "sociologia em mangas de camisa" em nome da rejeição à subserviência à cultura estrangeira.

Florestan opôs aos argumentadores da especificidade da realidade brasileira o argumento de que justamente o dado específico dessa realidade solicitava um procedimento científico rigoroso, amparado numa plataforma conceptual que não variava de local para local. Mas Florestan, acerca dessas questões, compartilhou experiências e argumentos junto a outra esfera da inteligência nacional, como se verá adiante.

Essa tradição realista, inaugurada com Paulino José Soares de Souza e que prosseguiu - mesmo que com descontinuidades pontuais - até Alberto Guerreiro Ramos, foi responsável por um estilo específico de enquadramento das imagens de Brasil que, a partir do início do século, ficaram também marcadas pela pena de Euclides da Cunha.

Todos esses intelectuais, incomodados com a prática da transplantação de idéias, recorriam às imagens do Brasil barbárie oposto ao Brasil civilização, variando a entonação de um para outro e variando também a sim- patia em relação ao sertanejo, ao mestiço, ao interiorano, enfim.

Por intermédio da análise da idéia de regional, manifesta no projeto do Centro Regional de Pesquisas Educacionais de São Paulo (CRPE), como conseqüência do projeto do Centro Brasileiro de Pesquisas Educacionais (CBPE), pode-se perceber como um novo grupo de intelectuais lidou de forma diferenciada com o legado interpretativo herdado junto dessa essa tradição bastante influente.

Os temas do dualismo e da transplantação de idéias serão revisitados nos anos cinqüentas. Uma nova acepção de ciência, nesse caso, provocou o espraiamento de novas imagens do Brasil. É o que será analisado a seguir.

\section{Imagensdo Brasil na idéia de regional dos intelectuais do CBPE e dosCRPE}

A UNESCO, como agência para o desenvolvimento da educação, da ciência e da cultura junto à Organização das Nações Unidas, teve um papel fundamental na reformulação das ciências sociais e da pesquisa educacional no Brasil.

Dois momentos foram decisivos para que esse papel fomentador fosse desempenhado por essa agência. O primeiro deu-se em agosto de 1949, quando Arthur Ramos assumiu a direção do seu Departamento de Ciências Sociais. Como a UNESCO já vinha engendrando ações no sentido de combater o analfabetismo, Ramos acrescentou a esse esforço a necessidade de ampliação quantitativa e qualitativa dos estudos raciais e das pesquisas sobre a integração do negro e do indígena nas sociedades que se modernizavam (Maio, 1997).

O segundo momento está relacionado com à aproximação que se intensifica a partir de 1952 entre Anísio Teixeira e os especialistas que passam a visitar o INEP no Brasil, especialmente Charles Wagley, Jacques Lambert, Otto Klineberg, Andrew Pearse e Bertram Hutchinson (Xavier, 2000).

Tais episódios foram decisivos no processo de institucionalização das ciências sociais no Brasil que, a partir dos anos cinqüentas, passam por refundações teóricas e temáticas. Pode-se atribuir aos mesmos eventos a colaboração decisiva para a aproximação intensa que ocorreu entre sociólogos, antropólogos e educadores. 
Desde 1952, o contato entre aqueles intelectuais encaminhava a produção de surveys sobre o Brasil como um todo e sobre sua educação em particular. Amadurecia também a idéia de prover o Estado brasileiro de um Centro de Altos Estudos Educacionais. Efetivamente, naqueles anos, ao redor de Anísio Teixeira nasciam as mais importantes instituições de inteligência não-universitárias que o Brasil possuiu ao longo do século XX.

Em todos esses momentos a preocupação com a diversidade cultural brasileira tornou-se constante. A partir dessa inquietação coletiva, o tema da multiplicidade tornou-se um renovado desafio teórico e investigativo. As diferenças entre as realidades locais, regionais e nacionais tornavam-se novamente objeto das ciências sociais que se associavam então à educação. Associadas, ambas as frentes de investigação lançam mão de um novo empirismo (Corrêa, 1987 e 1988).

Com esse espírito foi fundado no Rio de Janeiro, em 28 de dezembro de 1955, o Centro Brasileiro de Pesquisas Educacionais que tinha por adjuntos os Centros Regionais de Pesquisas Educacionais. Os Centros Regionais foram alocados em Recife, Salvador, Belo Horizonte, São Paulo e Porto Alegre (CBPE, Documentos Iniciais, 1956, p. 15).

No organograma do CBPE existiam, entre outras, a Divisão de Estudos e Pesquisas Educacionais e a Divisão de Estudos e Pesquisas Sociais. No âmbito dessas Divisões, os chamados estudos de caso ganharam grande visibilidade. Com o intuito de conhecer a singularidade de cada local e de compreender o complexo relacionamento entre escola e comunidade, organizaram-se programas que associavam a antropologia à sociologia da educação. Dentre esses projetos, um dos mais conhecidos - e polêmico - foi o Programa de Pesquisas em Cidades Laboratório, idealizado por Darcy Ribeiro quando coordenava a Divisão de Estudos e Pesquisas Sociais.

Em poucos anos o projeto CBPE com os CRPEs envolveu intelectuais dos mais variados jaezes na "órbita Anísio Teixeira". Entre tantas, foram decisivas as intervenções e ações de Jacques Lambert, Almir de Castro, Jayme Abreu, João Roberto Moreira, Charles Wagley, Marvin Harris, Carl Withers, Adroaldo Junqueira Aires, Josildeth Gomes, Carlos Castaldi, José
Bonifácio Rodrigues, Orlando F. de Melo, L. de Castro Faria, Luiz Aguiar Costa Pinto, Fernando de Azevedo, Gilberto Freyre, Almeida Júnior, Antonio Candido de Melo e Souza, Lourival Gomes Machado, Bertram Hutchinson, Florestan Fernandes, Roger Bastide, Egon Schaden, Darcy Ribeiro, Maria José Garcia Werebe, José Mário Pires Azanha, Luiz Pereira e Celso de Rui Beisiegel. Alguns atuaram no âmbito do CBPE, outros, nos domínios dos Centros Regionais e uns poucos, em ambos.

Tratava-se de uma intelectualidade vigorosa, alguns ainda em formação, mas todos destinados a influenciar com seus escritos o debate nas várias áreas de atuação sobre as quais se espalharam nos anos seguintes. Naquele momento, muitos estavam sob o impacto da divulgação recente de conceitos antropológicos de cultura (Xavier, 2000) e isso os investia da condição de novos leitores das antigas dualidades projetadas na ainda influente tradição euclidiana.

Não se revogava energicamente a percepção do Brasil cindido em dois, ou cindido em muitos. Não se estabelecia um marco zero, mas uma inflexão substantiva se dava, com certeza. Com novas e mais elaboradas versões, o atraso e o moderno permaneciam dualizados e contrapostos. A impressão de que coexistiam vários tempos históricos simultaneamente estava mais viva do que nunca e era alimentada num espaço de interlocução bastante próximo, o Instituto Superior de Estudos Brasileiros, o ISEB, também fundado em 1955.

Os ecos dos sertões ainda se faziam ouvir e geravam perplexidade. Imagens mais apuradas dessa realidade começam a ser oferecidas tanto no âmbito universitário quanto "nas tribunas" de opinião que coadjuvavam o trabalho dos Centros, como, por exemplo, a Revista Brasileira de Estudos Pedagógicos, a revista Educação e Ciências Sociais, o boletim Pesquisa e Planejamento do CRPE de São Paulo e as publicações de porte editorial mais amplo, como a Revista Anhembi, quase que uma "parceira informal" dos novos antropólogos, e a Revista Brasiliense.

A perspectiva de uma realidade dual, tratada com renovados critérios, revelava que - a partir daquele momento - a ênfase recairia muito mais sobre o desequilíbrio entre o urbano e o rural, do que entre a civili- 
zação e a barbárie. Os espaços rurais sugeriam imagens da sobrevivência de estruturas arcaicas e os espaços urbanos sugeriam imagens da convivência de estruturas provincianas com outras cosmopolitas. Quase sempre se descrevia um país sem homogeneidade. O caráter heterogêneo da nação, todavia, só podia ser apreendido com o olhar minudente do estudo de caso, da análise do exemplo singular, da observação de realidades-modelo. Ao mesmo tempo em que despontam estudos como Os parceiros do Rio Bonito de Antonio Candido, a sociologia da educação começa a ser articulada com a idéia da pesquisa de campo e a antropologia renova o ímpeto de discutir as questões raciais ainda efervescentes.

A profecia euclidiana - progredir ou desaparecerainda estava presente. Enquanto institutos como o ISEB produziam reflexões sobre as "permanências feudais" na sociedade brasileira, os "mapas culturais" propostos pelos pesquisadores dos centros explicitavam o problema da mobilidade social nas pequenas e grandes comunidades.

Contudo, mesmo que ainda na esteira dos dois Brasis, novos pontos de vista passam a ocupar aquelas "tribunas" e a dialogar com o passado recente da "tradição realista" brasileira. Em 1955, Pedro Gouvêa Filho, Diretor do Instituto Nacional de Cinema Educativo, trazia às páginas da Revista Brasileira de Estudos Pedagógicos palavras de Roquete-Pinto para lembrar que para além de Os sertões - o livro Rondônia deveria ser tomado como contraponto na retomada da relação entre educação e antropologia:

[...] penso que Os Sertões será no futuro, para o Brasil, o grande livro nacional; o que D. Quixote é para a Espanha ou $O s$ Lusíadas para Portugal; o livro em que a raça encontra a floração das suas qualidades, o espinheiral dos seus defeitos, tudo o que, em suma é sombra ou luz na vida do povo. [...] Tudo em Os Sertões é grandioso; mas nem tudo porém é certo. Já tive ocasião de mostrar quanto me parecem precárias três afirmativas de Euclides da Cunha: sobre a questão do cruzamento, a fatalidade da luta das raças, o autoctonismo do homem americano. (Roquete-Pinto apud Gouvêa Filho, 1955, p. 38-40)

O livro Rondônia passa a ser considerado academicamente o sucessor antropológico de Os sertões. No bojo desse reconhecimento cristaliza-se a percepção de que, nos estudos de caso, não sobreviveriam grandes generalizações postas até então como signos da cultura brasileira.

A pesquisa educacional, tocada por essa motivação, passa a apoiar-se em procedimentos típicos da pesquisa de campo, da observação etnológica e etnográfica. Esperava-se que um "mapa cultural" do Brasil pudesse colaborar na feitura de um "mapa educacional" e viceversa. A representação da sociedade como uma realidade dual torna-se uma mediação entre a identificação dos dados únicos observáveis em cada local e sua relação com os ritmos do desenvolvimento nacional:

A expressão mapa cultural está naturalmente sendo usada como um símbolo, para representar um conhecimento completo da cultura brasileira contemporânea, no seu sentido mais amplo, incluindo vida de família e criação de filhos; atividades econômicas e sociais, o uso do tempo de lazer, atitudes psicológicas, objetivos e ideais, com a devida atenção à herança religiosa e ética do povo. [...] O mapa educacional deverá conter, também, um componente psicológico, representado pelas atitudes do povo em relação às escolas, o grau e natureza da satisfação e descontentamento, os desejos e esperanças - e possivelmente também os temores - relativos à educação, qual a contribuição prática que o povo poderá dar à escola e assim por diante. [...] Se o antropólogo social tiver sido designado pelo Centro para elaborar um estudo de comunidade, é de se esperar que ele dedique atenção especial ao papel da escola na comunidade, à escola como instituição, à composição (econômica, social, étnica) da população da escola, às atividades e ocupações dos educandos, ao status dos professores etc. (RBPE, v. 24 n. 59, jul.-set. 1955, p. 119-121)

Esse olhar antropológico sobre a escola e a comunidade trouxe novos componentes para o debate sobre a identidade cultural do Brasil. No âmbito dos Centros Regionais as "reorganizações conceptuais" ganharam luz própria.

De início, as ações mais consistentes provieram do Centro Regional de Recife, dirigido por Gilberto Freyre, e do Centro Regional de São Paulo, dirigido por Fernando de Azevedo. O que será importante assinalar é que os Centros Regionais proporcionaram novas possibilidades à compreensão da relação entre o conhecimento regional e a cultura assim chamada nacional. 
Gilberto Freyre assumiu a coordenação do Centro de Recife e, logo de início, propôs que o conhecimento regional fosse tomado, a partir de então, não como uma "vitrine de caipirismos", mas como elemento "orgânico" do conhecimento nacional (Freyre, 1958, p. 105).

Naquele contexto, o autor de Nordeste tinha o prestígio consolidado, mas já havia sido indagado sobre o real poder elucidativo de seus escritos publicados nos anos trintas e quarentas. Já estava instalado, no seio da intelectualidade do Rio de Janeiro e de São Paulo, um debate sobre a abrangência do caráter descritivo presente na história da sociedade patriarcal tecida por Freyre. Discutia-se, através desse debate, se o que fora cabível para determinada realidade sociogeográfica - o Nordeste - poderia ser considerado um instrumento descritivo para o Brasil tout court (Azevedo, 1955, p. 1617).

Freyre, quando assumiu o Centro Regional de Recife, evocou o Manifesto Regionalista de 1926 e sugeriu que, mesmo estando noutro contexto, o regionalismo fosse interpretado como instrumento heurístico da identificação do quão complexa era a unidade nacional brasileira. Propunha então que os educadores e os cientistas sociais iniciassem a busca por culturas primitivas ainda sobreviventes. Tais culturas poderiam enriquecer a cultura nacional despertando nela espontaneidade e vitalidade. Ao mesmo tempo, pronunciava que as ações do Centro de Recife poderiam proporcionar àquele acervo cultural diluído nos regionalismos a passagem do âmbito da cultura oral para o âmbito da cultura escrita (Freyre, 1958, p. 108).

A opinião que Fernando de Azevedo vinha emitindo sobre o tema regionalismo é uma evidência do quanto as dualidades herdadas junto ao início do século eram, ao mesmo tempo, ratificadas e retificadas.

No estudo Para a análise e interpretação do Brasil: pequena introdução ao estudo da realidade brasileira, Azevedo pontuou, logo de início, que para conhecer o Brasil era fundamental a leitura das obras de Varnhagem, Tavares Bastos, Capistrano de Abreu, João Ribeiro, Pandiá Calógeras, Manoel Bonfim, Celso Garcia, Afonso Taunay, Silvio Romero, Euclides da Cunha, Oliveira Vianna e Gilberto Freyre (Azevedo, 1955, p. 4).
A indicação de Azevedo ampliou a recorrência à "tradição realista" e emendou-a com Gilberto Freyre. Contudo, embora Azevedo reconhecesse, na esteira dessa tradição, a existência de "camadas sociais superpostas e hierarquizadas" e a convivência de "muitos brasis dentro de um mesmo Brasil" (Azevedo, 1955, p. 8-13), procurou marcar a diferença de seu ponto de vista em relação ao do autor de Casa Grande \& Senzala:

\section{[...] as conclusões de Gilberto Freyre não se aplicam, a despei- to da tendência a generalizá-las, nem a todo o país, nem mes- mo ao ciclo do café, no período em que se desenvolveu, com o suporte da escravidão. (Azevedo, 1955, p. 16-17)}

Essa percepção de que o conhecimento regional deveria ser assimilado conforme uma variedade de significados que "ainda precisavam ser explicitados com outros critérios", tornou-se uma marca visível nos estudos que se encaminharam nas Divisões de Pesquisa Educacional e de Ciências Sociais dentro do Centro Regional de São Paulo.

$\mathrm{Na}$ esfera de suas ações, Azevedo reconhecia, simultaneamente, que

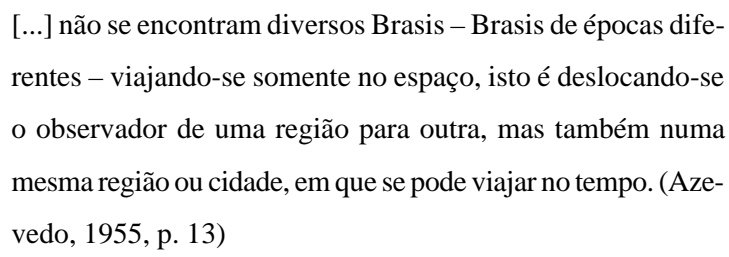

Havia também um encaminhamento metodológico que diferenciava a observação de Azevedo em relação à de Gilberto Freyre. Para Fernando de Azevedo e para os intelectuais que foram agregados ao projeto do Centro Regional de São Paulo, os muitos brasis tornavam o Brasil um "imenso laboratório de sociologia experimental" (Azevedo, 1955, p. 14).

Um deslocamento conceptual ocorreu ao longo do processo aqui narrado, em decorrência da forma através da qual Azevedo e seus pares no Centro Regional de São Paulo compreenderam a justaposição de tempos históricos e a sobrevivência de arcaísmos.

À medida que associaram a leitura histórica que tinham a procedimentos metodológicos experimentais, deslocaram a idéia de regional para o debate sobre a realidade das cidades. Desejava-se explicitar os moti- 
vos pelos quais os "fenômenos de demora cultural" e a "tendência à inércia da cultura brasileira" incidiam sobre a esfera urbana gerando o mesmo imobilismo do mundo rural, que ainda permanecia à mercê do passado. Havia um sertão em cada cidade.

No Rio de Janeiro, essa mesma inclinação perpassava os escritos de José Roberto Moreira. Em mais de uma oportunidade, o estudioso salientou a necessidade de reunir em um só propósito a pesquisa educacional e a antropologia cultural. Considerava que a identificação de estratos arcaicos sobreviventes nas comunidades urbanas poderia indicar os instrumentos mais precisos para o planejamento educacional (Moreira, 1956, p. 13-14).

No Rio de Janeiro, o encaminhamento dos estudos de comunidade no Programa Cidades Laboratório direcionava o curso das investigações da metrópole para as pequenas cidades, com projetos coordenados por Oracy Nogueira, com a colaboração de Aparecida Joly Gouveia, Orlando Valverde, Juarez Rodrigues Brandão Lopes, Carolina Martuscelli e Bertram Hutchinson (Nogueira, 1959, p. 47). Em São Paulo, o movimento se dava no sentido inverso. As "setorizações", ou seja, a localização de comunidades dentro das comunidades na maioria das vezes se dava no amplo espaço da capital paulista, cada vez mais complexa. A cultura local e a idéia de regional numa metrópole como São Paulo passavam por outras significações. Isso, naquele contexto, era consensual na comunidade de educadores envolvida com o projeto dos Centros.

De uma certa forma, Anísio Teixeira já havia antevisto a dificuldade própria ao estudo das realidades urbanas quando inaugurou o Centro Educacional Carneiro Ribeiro, em 1950. As metáforas da aceleração do tempo tornavam-se instrumentos descritivos fundamentais. No evento de inauguração comentou:

Os habitantes deste bairro Liberdade deixam um estágio anterior aos tempos bíblicos de agricultura e vida primitiva para imergirem em pleno báratro do século vinte. (Teixeira 1950, p. 78)

A imagem do tempo estanque convivia com a hipótese de que o tempo histórico poderia ser deslocado ou acelerado. Não se deve perder de vista que Anísio Teixeira - a espinha dorsal desses projetos -, mesmo quando ampliou sua perspectiva de análise incorporando cada vez mais a leitura de autores estrangeiros, nunca abandonou a motivação regionalista e a consciência do problema do sertão (Schaeffer, 1976, p. 8).

De certa forma, pode-se dizer que, ao incentivar a instalação e a proliferação de estudos de caso, encaminhou, à sua maneira, a solução para questões percebidas muito antes, no momento de leitura e assimilação das metáforas euclidianas:

$\mathrm{Na}$ linha de pensamento consagrada por Euclides da

Cunha, o educador baiano faz insistentes apelos para que a ação governamental no sertão, em qualquer que seja o âmbito, não desconheça as peculiaridades da organização social que vai enfrentar. O problema da ordem no sertão, por exemplo, deve ser enfrentado com a exata consciência de que o problema da legalidade nos sertões é um problema sociológico e não policial. (Schaeffer, 1976, p. 9)

Esse era um cuidado que partia do fomentador dos projetos e que repercutia intensamente nas propostas de cada um que se envolvia com as atividades regionais dos Centros. Na cidade de São Paulo, por exemplo, a própria idéia de peculiaridade sugeria um curso diferenciado para as investigações. Os boletins publicados constantemente reforçavam a utilização do slogan "cada escola é uma escola”, o que significava um entendimento conjunto sobre a unidade escolar como unidade sociológica e antropológica (Educação e Ciências Sociais, 1956, n 1, p. 20).

Dois ensaios produzidos por Antonio Candido, “A estrutura da escola", publicado em 1956 como separata do Boletim do Centro Brasileiro de Pesquisas Educacionais, e "as diferenças entre o campo e a cidade e seu significado para a Educação", publicado em 1957 na Revista Pesquisa e Planejamento do Centro Regional de Pesquisas Educacionais de São Paulo, são exemplos relevantes daquela nova forma de se compreender a escola e a vida escolar.

Candido propôs a elaboração de um trato sociológico específico para a realidade escolar, alertando para a complexidade da vida social interna em cada unidade. Esse procedimento, no seu entender, induziria o observador a perceber e a relatar o que cada escola possuía de único em relação às demais (Candido, 1956, p. 1-2). 
O autor observava que cada escola conservava em seu interior elementos comuns a todo o complexo civilizatório envolvente e isso, asseverava, tornava necessário estabelecer as diferenciações internas em cada grupo de sociabilidade (Candido, 1956, p. 3). Isso o conduziu à observação apurada e minudente de cada detalhe da vida socioescolar. Notou, por exemplo:

A importância do sistema simbólico de uma escola, inclusive a sua tradição, [que] se manifesta nitidamente no conjunto de sanções impostas aos neófitos - os calouros, sujeitos em todas as partes do mundo a provações que vão da simples caçoada de meninos às práticas brutais e deprimentes das escolas superiores. O grupo, cônscio do seu significado, reforça a solidariedade entre os próprios membros pelo tributo cobrado aos que nele ingressam. (Candido, 1956, p. 19)

Contudo, se os componentes internos da escola sugeriam diferentes processos de observação e diferenciação, as diferenças entre o campo e cidade encareciam ainda uma maior acuidade. Nesse sentido, ao cientista social, as observações de Candido permitem reconhecer a inflexão em relação à tradição realista do início do século, ou em relação à conceituação herdada de Euclides da Cunha. A distância entre o campo e a cidade não correspondia mais à distância entre civilização e barbárie. A idéia de regional é tomada com ampla reorientação de signos.

Henri Lefebvre oferecia argumentos para Candido enumerar as desigualdades básicas da modernidade: entre homem e mulher, entre ricos e pobres e entre citadinos e camponeses (Candido, 1957, p. 53).

A dualidade presente na sociedade brasileira passa a ser pensada como uma diferença arraigada entre mentalidades agrárias e mentalidades urbanas. À medida que se intensificava o deslocamento do campesino para a cidade, a concentração demográfica provocava uma aceleração no ritmo de vida daquele que, ao mesmo tempo, perdia o hábitat e ganhava um novo espaço existencial. A "profanação" das características que trazia arraigadas dentro de si, tornava o homem recém-chegado à cidade um fiel depositário de suas mais caras tradições, as quais só podiam ser preservadas enquanto mentalidade (Candido, 1957, p. 58).

A sociedade brasileira se caracterizava pela existência de uma forte oposição entre a vida urbana e a rural. Naquele momento, porém, parecia ao autor estar em curso a superação dessa oposição mediante a possibilidade da supressão relativa de um dos seus termos. Como esse era um processo que se iniciava a todo momento, sem contudo concluir-se, a supressão era sempre parcial e, por isso, microcidades de mentalidade rural sobreviviam dentro e ao lado das zonas citadinas, que não chegavam a ser um todo de mentalidade urbana (Candido, 1957, p. 59-60). Conviviam formas avançadas de vida cosmopolita com sobrevivências do passado (p. 60), mesmo num momento no qual a predominância da cultura urbana sobre a rural tornava-se inexorável.

Candido considerava o ruralismo uma ilusão e reconhecia que o sentido civilizatório em curso possibilitava entrever em poucos anos a superação da diferença entre campo e cidade. $\mathrm{O}$ autor de Os parceiros do Rio Bonito criticou com veemência a tradição interpretativa que tomava o homem do campo como uma espécie de reserva humana da nacionalidade e da autenticidade. Todavia, esclarecia que não era possível negar que um processo permanentemente incompleto revelava a necessidade de adaptação de programas escolares às diferenças que faziam do meio rural uma outra realidade.

$\mathrm{Na}$ procura pelo adequado conhecimento local, Candido trouxe ao Centro Regional de São Paulo indicadores para uma compreensão antropológica da escola e passou, com isso, a ser acompanhado por outros investigadores, tais como Dante Moreira Leite, o qual completou o argumento de Candido nos seguintes termos:

Se o início da civilização industrial desorganiza a família tradicional e as formas tradicionais de proteção à infância, (como o apadrinhamento), precisa criar instituições que as substituam. Compreende-se, assim, que a escola deixe de ser uma instituição voltada, exclusivamente, para o preparo intelectual e passe a desempenhar a função muito mais ampla de ajustar a criança à vida social. (Leite, 1958, p. 16)

Essas novas funções da escola não se apresentavam à sociedade na forma de uma nova legislação a ser cumprida. Correspondiam sim a um novo entretecer da cultura com a atividade escolar, sobre o qual a atividade de pesquisa educacional ainda tinha pouco a dizer e, por isso, reorganizava seus métodos e buscava novas interlocuções noutras disciplinas. 
Supunha-se que, naquela fase da história do Brasil, todo esse processo de adaptação e desadaptação estivesse acontecendo em dois planos: no regional em relação ao nacional e no nacional em relação ao mundo ocidental moderno. Justificava-se, então, que os esforços intelectuais mais intensos fossem dirigidos à pesquisa local, ao conhecimento da escola caso a caso, uma vez que as pequenas unidades de cultura eram ainda universos desconhecidos do ponto de vista das novas práticas experimentais.

Mas os intelectuais investidos dessa preocupação, no âmbito dos Centros Regionais e do Centro Brasileiro, não eram homogêneos, e o debate interno evidenciava algumas diferenças no encaminhamento das pesquisas.

Florestan Fernandes envolveu-se ativamente com o projeto dos Centros em quase todas as etapas, desde o planejamento até sua concretização. Seu momento de maior envolvimento com o Centro Brasileiro de Pesquisas Educacionais deu-se na fase de planejamento, quando foi escolhido como debatedor do documento inicial, escrito por Oto Klineberg. No Centro Regional de São Paulo sua atuação foi mais intensa na primeira gestão, de Fernando de Azevedo, entre 1956 a 1961, continuando, logo após, como colaborador na gestão de Laerte Ramos de Carvalho.

O sociólogo paulista, tanto quanto Anísio Teixeira e seus pares, foi um prolífico produtor de imagens do Brasil. Se, naquele momento, essas imagens eram retiradas de um "olhar microscópico" sobre a sociedade, Florestan participava do processo discutindo o encaminhamento metodológico necessário para que as imagens não se tornassem distorções da realidade.

Mais do que um colaborador, Florestan foi um analista constante dos rumos tomados pelos estudos de comunidade. Mais tarde, em 1969, a publicação de Сотиnidade e sociedade no Brasil revelará a importância do tema ao longo de sua trajetória acadêmica.

Na esfera do Centro Regional de São Paulo, Florestan manteve um tom de reserva quanto à trajetória do grupo dos educadores pioneiros, no que diz respeito à visão otimista que sustentaram sobre as transformações tentadas nos domínios da educação pública:
As forças que lutaram pela educação nova jamais conseguiram êxito completo porque a persistência desse padrão sempre impediu, cronicamente, que se explorasse a educação escolarizada segundo modelos pedagógicos modernizados. Até um princípio que decorria de preceitos constitucionais e básico para o funcionamento do sistema democrático de educação, o da laicidade do ensino público, recebeu interpretações deformadoras e foi solapado de maneira tortuosa. O pior de tudo é que a existência dessas forças renovadoras engendrou a ilusão de que estaria ocorrendo uma modernização relativamente extensa e intensa das instituições escolares. (Fernandes 1963, p. 151)

É importante relembrar que a organização dos Centros possibilitou uma linha de contato acadêmico entre Florestan Fernandes e Anísio Teixeira. Esse contato reeditava-se politicamente na luta em defesa da escola pública. Divergências à parte, esse encontro entre ambos deve ser reconhecido como um encontro de águas, no qual as imagens de um país privatizado "por dentro" assumiam o tom de denúncia política e de crítica histórica e historiográfica.

Na elaboração das diretrizes do Centro Brasileiro de Pesquisas Educacionais e do planejamento do trabalho das Divisões de Pesquisa, Florestan manifestou um ponto de concordância em relação ao documento base, assim sintetizada por José Mário Pires Azanha:

A idéia principal desse documento era a de que os Centros deveriam organizar-se com o objetivo de elaborar um mapa cultural do Brasil e um mapa educacional [...]. A idéia fundamental era de que nós não tínhamos conhecimento sistematicamente organizado sobre o Brasil; embora tivéssemos aí, centenas, milhares de estudos feitos ao longo de séculos de existência do país, nós não tínhamos tido a preocupação de uma obra de síntese, - que fosse capaz de nos dar um mapa cultural do Brasil e um mapa educacional do Brasil. A idéia do Prof. Klineberg é a de que a feitura desses mapas seria o ponto de partida para um esforço de descentralização das soluções educacionais brasileiras; o Brasil, por força da própria tradição portuguesa, por força da própria organização política que, de um lado, foi capaz de preservar a integridade do território, de outro conferir sempre a nossa organização política uma forte centralização. Então, a idéia dele é de que um esforço de descentralização poderia ser superficial e até inútil, se não levasse 
em conta fortes características de diferenciação cultural, social e educacional, que nós tínhamos. (Azanha, 1959, p. 27)

Quanto às restrições que Florestan opôs ao projeto, Azanha relatou sua preocupação com a suposta falta da dimensão histórica na realização dos mapas culturais, desconfiando do excesso de procedimentos antropológicos. Florestan temia a disseminação de uma visão estática da realidade (p. 28) e o abandono da compreensão de que a sociedade é permanentemente móvel e plástica (p. 28). Considerava também que os mapas poderiam ser insuficientes para subsidiar a renovação das políticas educacionais, posto que estas estavam relacionadas diretamente com a história política do Brasil, cuja apreensão extrapolava as bases dos estudos de caso (p. 29).

A influência de Florestan Fernandes no Centro Regional de São Paulo fazia-se notar também na ação de vários acadêmicos formados sob sua orientação. É possível que Luiz Pereira seja - dentre os assistentes de Florestan envolvidos com o Centro Regional de São Paulo - o responsável pela produção dos melhores exemplos do deslocamento da idéia de regional na pesquisa educacional em São Paulo.

Enquanto os pesquisadores vinculados ao Centro Regional de São Paulo produziam levantamentos sobre a leitura e a escrita nas escolas da capital paulista, sobre questões administrativas nas unidades escolares, sobre a fadiga entre estudantes na cidade de São Paulo, sobre a relação entre o ensino médio e a estrutura socioeconômica, alguns grupos escolares eram escolhidos como laboratório de estudo. Nesse caso, as unidades escolhidas permitiam a observação de escalas de escolaridade. Ao mesmo tempo, colaboradoras como Ruth Cardoso produziam monografias para o Centro Regional, tais como "Associações nissei em São Paulo".

No caso de Luiz Pereira, as observações colhidas no projeto "Rendimento e deficiências do ensino primário" (CRPESP-1959) provocaram a recepção essencialmente urbana da metáfora dos dois brasis, como se vê, a mais longeva imagem síntese do Brasil.

A argumentação de Luiz Pereira concluiu um ciclo de observações, através das quais o problema da falta de homogeneidade na sociedade brasileira compareceu como figura-chave das análises que pediam a transfe- rência do debate educacional para os domínios da planificação racional, e, nesse caso, Karl Mannheim era uma leitura de fundo visível na maioria dos documentos analisados.

A dualidade básica percebida por Luiz Pereira revelava que:

Também as camadas inferiores das comunidades citadinas vivem segundo um estilo não inteiramente urbano. Os contingentes migratórios vêm a fazer parte delas, permanecendo como portadores de muitos complexos da cultura rústica, continuando a viver o rural na cidade. (Pereira, 1959, p. 1. Grifo no original)

Observa-se a consolidação da imagem síntese na qual a mentalidade rústica tornou-se o contraponto da mentalidade urbana. Dois brasis existiam não somente na distância entre o litoral e o sertão, mas, substanciosamente, na dificuldade que a cultura urbana encontrava em fazer-se vetor de racionalização do país como um todo, para o que a escola deveria tornar-se uma racionalizadora de cada comunidade em particular.

A presença dessa dualidade, no entender desses intelectuais diante de seu objeto, era politicamente o componente necessário para a subsistência de um país privado dentro da res pública. Essa realidade criava obstáculos à disseminação da escola como serviço público, através do qual o saber escolar pudesse colaborar na aceleração do tempo para as comunidades que ainda sobreviviam em "outras épocas", estivessem no campo como organização familiar, estivessem na cidade como mentalidade arcaica.

Dizia Luiz Pereira:

A análise desse conteúdo cultural da atividade ensinoaprendizagem mostra ser ele parte do patrimônio cultural de camadas citadinas sócio-econômicas não inferiores e evidencia a ligação estreita desse conteúdo cultural com um estilo urbano de vida, possuído principalmente por tais camadas. A transmissão desse conteúdo implica, portanto, na comunicação de um estilo urbano de vida social, cultural e econômico. Assim sendo, o subgrupo de ensino primário atua nas comunidades rurais e semi-rurais, como agência de desintegração de um estilo não urbano de vida e, ao mesmo tempo, como agência de urbanização. (Pereira, 1959, p. 1) 
Quais seriam os efeitos políticos esperados do ato de conhecer as realidades locais com o objetivo de efetivar o planejamento escolar? O que o observador poderia depreender da associação entre a escola urbana e a mentalidade rural?

[...] avulta a função urbanizadora desta associação, realizada sob formas específicas várias: integração dos brasileiros numa comunidade nacional com base numa cultura urbana; [...] desintegração do estamentalismo e outros frações de estrutura social das comunidades rústicas... (Pereira, 1959, p. 1)

Ficavam para trás, cada vez mais, como passado enterrado, as imagens da realidade brasileira originadas no século XIX e conduzidas como estandarte pela tradição realista referida ao início. Com outras formas, algumas imagens tecidas por Euclides da Cunha ainda sobreviviam e, felizmente, sem vezos racistas, eram reeditadas com escrúpulo metodológico e partilha acadêmica.

Teimosamente, a realidade oferecia à observação, tanto nas cidades-laboratório quanto nas cidades-metrópoles, tipos humanos complexos que, vistos de perto, revelavam o imenso desafio presente na junção da história e da antropologia com a pesquisa educacional.

Todos esses pesquisadores, ciosos de conhecer o homem brasileiro e sua mentalidade, foram contemporâneos de Guimarães Rosa. Talvez a opinião de Riobaldo Tatarana pudesse acrescentar elementos preciosos aos trabalhos em curso.

\section{Consideraçõesfinais}

A referência a Guimarães Rosa não é acidental. O grande sertão e suas veredas persistiu como referência aos novos encaminhamentos metodológicos usados nos anos cinqüentas. A diferença mais aguda entre as falas euclidianas e a fala dos "antropólogos da educação", ou entre a tradição realista e as pesquisas de campo, está relacionada com a renovação do acervo de metáforas sobre o arcaísmo cultural.

De certa forma, o sertão deixou de ser exclusivamente o lugar ermo, distante da civilização, para tornarse, também, o micropaís dentro das macrocidades. O prestígio obtido por dois livros publicados entre os anos cinqüenta e setenta mostra a longevidade da imagem dos dois países convivendo num só: um deles foi Os Dois Brasis, de Jacques Lambert, o outro foi Brasil: terra de contrastes, de Roger Bastide.

De certa forma, tais livros arremataram um itinerário intelectual percorrido em décadas de estudo sobre a "personalidade da nação". Ficaram para trás as imagens grandiloqüentes do espelho de Euclides. Sofreram forte abalo as idéias acalentadas nas páginas da tradição realista que vinha do século XIX. Adquiriram o tom e a feição de trabalho acadêmico as iniciativas de pesquisa que, ao redor de Anísio Teixeira e dos Centros Regionais, propuseram uma retomada das "sínteses de Brasil". A (re)descoberta do cotidiano ofereceu novas fronteiras ao pensamento social brasileiro diante do qual os educadores tornaram-se interlocutores privilegiados, uma vez que se propuseram a ser, também, intérpretes do Brasil, à mercê da ciência que buscavam e das imagens que refaziam.

Jacques Lambert descrevia a sociedade dualista com os seguintes argumentos:

A situação no Brasil não é tão séria porque não se trata, nem de duas raças, nem de dois povos formando duas sociedades diferentes, mas de indivíduos que professam a mesma religião, falam a mesma língua, e têm a mesma nacionalidade, a mesma história e a consciência da sua solidariedade. Não há qualquer obstáculo, além do econômico, à transição de uma sociedade para outra, o que não impede que o Brasil precise urgentemente difundir por todo o país os níveis e métodos de vida das regiões evoluídas. (Lambert, 1973, p. 106-107).

Há um certo simplismo na análise de Lambert. Ela é, contudo, um eco tardio das tradições interpretativas que produziram e reproduziram imagens do Brasil dual. Roger Bastide, de certa forma, tentou avançar esse debate ao propor que as dualidades fossem interpretadas como uma sucessão de contrates que, na história do país, correspondiam a uma unidade de problemas tipicamente brasileiros:

Todos os contrates de terra e vegetação, de raças e de etnias, de costumes e de estilos, permanecem brasileiros. Todas as oposições de velocidade e lentidão não impedem que o tempo, que ora parece estagnar preguiçoso, ora se precipita 
para o futuro, seja sempre o mesmo tempo brasileiro. Até agora, foi focalizada a harmonização dos contrários, água e fogo, açúcar e café, litoral e sertão, e verificou-se que as civilizações antagônicas, a do gaúcho no sul e a do vaqueiro no norte, a do fazendeiro e a do industrial, a do negro e a do imigrante, são antes complementares do que antagônicas. Mas há uma unidade mais profunda do que a da simples complementariedade entre elas; por toda a parte, são encontrados os mesmos problemas fundamentais, impostos pelo meio geográfico ou herdados da História. (Bastide, 1971, p. 232)

O autor evoca a História, grafada com letra maiúscula. Essa evocação, para além de engrandecer a história como campo de ciência, talvez quisesse revelar a necessidade de reavalição constante do passado. Uma vez que o país "nem progrediu, nem desapareceu", contrariando o que supunha Euclides da Cunha, talvez o olhar minudente sobre a realidade ainda possa ser revelador. Talvez o movimento iniciado pelo Centro Brasileiro de Pesquisas Educacionais e pelos seus Centros Regionais deva ser retomado. O Brasil permanece à espera de quem o conheça, de perto.

MARCOS CEZAR DE FREITAS é coordenador do Centro de Documentação e Apoio à Pesquisa em História da Educação CDAPH - do Instituto Franciscano de Antropologia da Universidade São Francisco.

E-mail: marcoscf@uol.com.br

\section{ReferênciasBibliográficas}

\section{A RECONSTRUÇÃO EDUCACIONAL NO BRASIL - ao povo e ao} governo. Manifesto dos Pioneiros da Educação Nova. CRPESP, Dossiê Anísio Teixeira. Arquivo do Centro de Memória da Educação da FEUSP.

ARANTES, Paulo, (1992). Sentimento de dialética. Rio de Janeiro: Paz e Terra.

AZANHA, José Mário Pires, (1959). Pesquisa educacional no CRPE. Dossiê INEP, CRPESP, CRPE, AS, 81 (32): 27-31.

AZEVEDO, Fernando, (1955). Para a análise e interpretação do Brasil: pequena introdução ao estudo da realidade brasileira. Revista Brasileira de Estudos Pedagógicos, Rio de Janeiro: INEP, v. 24 n. 60 , out.-dez., p. 3-29.
BASTIDE, Roger, (1971). Brasil: terra de contrastes. São Paulo: DIFEL.

BUFFA, Ester, (1979). Ideologias em conflito. São Paulo: Cortez \& Moraes.

BRASIL. MEC. Informe CBPE, (1955). nº 59, p. 119-121.

BRASIL. MEC. INEP, CBPE, (1956a). Educação e Ciências Sociais. Rio de Janeiro: $\mathrm{n}^{\circ} 1$.

(1956b). Documentos iniciais. P. 15.

CANDIDO, Antonio, (1956). A estrutura da escola. Separata do Boletim CBPE, Rio de Janeiro, CBPE, INEP.

, (1957). As diferenças entre o campo e a cidade e o seu significado para a educação. Revista Educação e Planejamento, v. 1 n. 1 , p. $53-65$

(1964). Os parceiros do Rio Bonito. Rio de Janeiro: José Olympio.

(1988). O método crítico em Silvio Romero. São Paulo: EDUSP

CARVALHO, José Murilo de, (1998). Pontos e bordados. Belo Horizonte: Editora UFMG.

CORRÊA, Mariza, (1987). História da antropologia no Brasil. Campinas: EDUNICAMP.

(1988). A revolução dos normalistas. Caderno de Pesquisas. São Paulo: Fundação Carlos Chagas, p. 13-24.

, (1998). As ilusões da liberdade. Bragança Paulista: EDUSF.

CUNHA, Euclides da, (1996). Os sertões. Rio de Janeiro: Ediouro.

DE LUCA, Tania, (1999). Revista do Brasil, um diagnóstico para a (n)ação. São Paulo: ed. da UNESP.

DUARTE, Nestor, (1966). A ordem privada e a organização nacional. São Paulo: Companhia Editora Nacional.

FERNANDES, Florestan, (1963). A escola e a ordem social. Pesquisa e Planejamento. São Paulo: Centro Regional de Pesquisas Educacionais de São Paulo (CRPESP), 6, p. 137-153.

(1969). Comunidade e sociedade no Brasil. São Paulo: EDUSP.

(1980). A sociologia no Brasil. Petrópolis: Vozes.

FREITAS, Marcos Cezar de, (1998). Álvaro Vieira Pinto: a personagem histórica e sua trama. São Paulo, Cortez.

, (1999). Da micro história à história das idéias. São Paulo: Cortez. 
FREYRE, Gilberto, (1958). Discurso pronunciado pelo sociólogoantropólogo na instalação do Centro Regional de Pesquisas Educacionais do Recife. Educação e Ciências Sociais, Rio de Janeiro: CBPE, vol. 3, 7, p. 105-110. , (1967). Manifesto regionalista (1926). 4ㄹ ed. Recife: Instituto Joaquim Nabuco de Pesquisas Sociais - MEC. , (1976). Apresentação. In: CUNHA, Euclides da. Paraíso perdido. Petrópolis: Vozes.

GOUVÊA FILHO, Pedro, (1955). Roquete Pinto: antropólogo e educador. RBEP, Rio de Janeiro, INEP, v. XXIV, $\mathrm{n}^{\circ}$ 59, p. 38-40, jul./set.

JANOTTI, Maria de Lourdes Monaco, (1997). O diálogo convergente. In: FREITAS, Marcos Cezar de, (org.) Historiografia brasileira em perspectiva. São Paulo: Contexto.

KLINEBERG, Oto, (1956). Centro Educacional de Pesquisas Educacionais: Documentos iniciais. Separata de Educação e Ciências Sociais. Rio de Janeiro: CBPE, INEP.

LAMBERT, Jacques, (1973). Os dois brasis. São Paulo: Companhia Editora Nacional.

LEITE, Dante Moreira, (1958). O brinquedo, a leitura e a criança. Revista Pesquisa e Planejamento, v. 2, n. 2, p. 11-16. , (1992). O caráter nacional brasileiro. São Paulo, Ática.

LIMA, Nisia T., HOCHMAN, Gilberto, (1996). Condenado pela raça, absolvido pela medicina: o Brasil descoberto pelo movimento sanitarista da Primeira República. In: MAIO, Marcos Chor, SANTOS, Ricardo Ventura, (orgs.) Raça, ciência e sociedade. Rio de Janeiro: Editora Fiocruz.

LIMA, Nísia Trindade, (1999). Um sertão chamado Brasil. Rio de Janeiro: Revan.

LOBATO, Monteiro, (1999). Carta a Rangel. In: DE LUCA, Tania. Revista do Brasil: um diagnóstico para (n)ação. São Paulo: EDUNESP.

LUZ, Nícia, (1978). A luta pela industrialização no Brasil. São Paulo: Alfa-Ômega.

MAIO, Marcos Chor, SANTOS, Ricardo Ventura, (orgs.), (1996). Raça, ciência e sociedade. Rio de Janeiro: Editora Fiocruz.

MAIO, Marcos Chor, (1997). A história do projeto UNESCO: estudos raciais e ciências sociais no Brasil. Tese de Doutorado. Rio de Janeiro: IUPERJ.

MANIFESTO dos educadores mais uma vez convocados. $O$ Estado de S. Paulo, 1/07/1959.
MANIFESTO do Partido Republicano de 1870. São Paulo: mimeo.

MARTINS, José de Souza, (1998). Florestan: sociologia e consciência nacional. São Paulo: EDUSP.

MENDONÇA, Ana Waleska, BRANDÃO, Zaia, (orgs.), (1997). Uma tradição esquecida: por que não lemos Anísio Teixeira. Rio de Janeiro: Escolas de Professores.

MENEZES, Djacir, (org.), (1998). O Brasil no pensamento brasileiro. Brasília: Senado Nacional.

MICELI, Sérgio, (1979). Intelectuais e classe dirigente no Brasil. São Paulo: DIFEL.

MOREIRA, J. Roberto, (1956). Aspectos atuais da situação educacional de Pernambuco. Educação e Ciências Sociais, CBPE, Rio de Janeiro: INEP, nº 3, p. 21-75.

NOGUEIRA, Oracy, (1959). O problema cidades laboratório. RBEP, Rio de Janeiro: INEP, $n^{\circ} 73$, p. 47-52. , (1998). Preconceito de marca. São Paulo: EDUSP.

OLIVEIRA, Lúcia Lippi (1990). A questão nacional na primeira república. São Paulo: Brasiliense.

, (1995a). As ciências sociais no Rio de Janeiro. In: MICELI, Sérgio, (org.). História das ciências sociais no Brasil, v. II. Sumaré: FAPESP.

, (1995b). A sociologia do guerreiro. Rio de Janeiro: UFRJ.

PEREIRA, Luiz, (1959). Rendimento e deficiências do ensino primário. CRPESP, DEPES, PS, Caixa 1, doc. 1-21, fl. 522, p. 1. , (1967). A escola numa área metropolitana. São Paulo: EDUSP.

RAMOS, Alberto Guerreiro, (1957). Introdução crítica à sociologia brasileira. Rio de Janeiro: Andes. , (1965). A redução sociológica. Rio de Janeiro: Tempo Brasileiro.

REIS, José Carlos, (1999). As identidades do Brasil. Rio de Janeiro: Fundação Getúlio Vargas.

REVISTA DE CULTURA VOZES. Petrópolis: Vozes, 1961, p. 198. ROMERO, Silvio, (1910). Provocações e debates. In: MENEZES, Djacir, (1998). O Brasil no pensamento brasileiro. Brasília: Senado Federal. , (1979). Realidade e ilusões no Brasil. Petrópolis: Vozes. 
, (1881). Introdução à história da literatura brasileira. Revista Brasileira. Rio de Janeiro: Tipografia da Revista Brasileira, v. VIII, IX, X.

, (1888). História da literatura brasileira. Rio de Janeiro: Livraria Garnier.

SCHAEFFER, Maria Lúcia Pallares, (1976). Anísio Teixeira: uma motivação regionalista. O Estado de S. Paulo, 28/11, p. 7-8.

SEVCENKO, Nicolau, (1985). Literatura como missão. São Paulo: Brasiliense.

SILVA, Geraldo Bastos, (1965). Educação e desenvolvimento nacional. São Paulo: Centro Regional de Pesquisas Educacionais, Arquivo Centro de Memória da Educação FEUSP, mimeo.

SKIDMORE, Thomaz, (1976). Brasil: preto no branco. Rio de Janeiro: Paz e Terra.

SOUZA, Paulino José Soarez, (1960). Ensaio sobre o direito administrativo. Edição fac-similar de 1861. Rio de Janeiro, Editora Nacional.

TEIXEIRA, Anísio, (1950). Discurso de inauguração do Centro Educacional Carneiro Ribeiro. Centro Regional de Pesquisas Educacionais de São Paulo, Arquivo do Centro de Memória da Educação da FEUSP, Dossiê Anísio Teixeira, p. 78.
TORRES, Alberto, (1915). As fontes da vida no Brasil. Rio de Janeiro: Papelaria Brasil. , (1933). A organização nacional. Rio de Janeiro: Editora Nacional. , (1938a). A organização nacional. São Paulo: Editora Nacional.

(1938b). O problema nacional brasileiro. São Paulo: Editora Nacional.

VENTURA, Roberto, (2000). Um Brasil mestiço: raça e cultura na passagem da monarquia á república. In: MOTA, Carlos Guilherme, (org.). Viagem incompleta: formação histórica. São Paulo: SENAC, p. 329-360.

VIANNA, Francisco José de Oliveira, (1938). Evolução do povo brasileiro. São Paulo: Editora Nacional.

(1974). Instituições políticas brasileiras. 2 vols. Rio de Janeiro: Record.

, (1982). Populações meridionais do Brasil. Brasília: Câmara dos Deputados.

WEREBE, Maria José Garcia, (1970). Grandezas e misérias do ensino no Brasil. São Paulo: DIFEL.

XAVIER, Libania Nacif, (2000). O Brasil como laboratório. Bragança Paulista: EDUSF. 